\title{
Twilight in Afghanistan
}

An Introduction

After Considerable eXPenditure of both Blood and treasure, the United States has now effectively withdrawn from Afghanistan. As of January 20I5, over 2,200 U.S. servicemen and women have died in combat in that country, ${ }^{1}$ with more than 17,200 Afghan civilians dead. ${ }^{2}$ Further, according to a Pentagon estimate, the war has cost the U.S. \$30o million a day. ${ }^{3}$ Support for the war in the U.S. has begun to wane in Congress, and the Obama administration does not seem overly concerned about declining congressional support. ${ }^{4}$ U.S. allies, who have steadily reduced their presence in the country, also show signs of growing fatigue with their involvement as domestic support for the presence of their troops in Afghanistan has dramatically tapered off. ${ }^{5}$ Tensions in the bilateral U.S.-Afghan relationship have

Sumit Ganguly, director of the Indiana University Center for American and Global Security, is the Rabindranath Tagore Chair in Indian Cultures and Civilizations. FeISAL A. R. AL-Istrabadi, the founding director of the Indiana University Center for the Study of the Middle East, is Professor of the practice of international law and diplomacy. Emails: <sganguly@indiana.edu>, $<$ fistraba@indiana.edu>.

I. Associated Press, "U.S. Military Deaths in Afghanistan at 2,213," January I3, 20I5, at <http://news. yahoo.com/us-military-deaths-afghanistan-2-2I3-2II523225.html>, accessed on February II, 20I5.

2. Reuters, "Civilian Deaths in Afghanistan Reach New High in 20I4: U.N.," December I9, 20I4, at <http://www.reuters.com/article/2OI4/I2/I9/us-afghanistan-casualties-idUSKBNoJXIZS2OI 4I2I9>, accessed on February II, 20I5. (Note: the U.N. did not begin tracking Afghan civilian deaths until 2009.)

3. Agence France-Presse (AFP), “Afghan War Costs \$30o Million a Day: Pentagon,” February I4, 2OII, at <http://www.google.com/hostednews/afp/article/ALeqM5gNQ3JbWwd6t-PzkuECkR JvsAlNkA?hl=en>, accessed on January 25, 2014.

4. Ernesto Londono and Karen DeYoung, "Congress Cuts U.S. Military and Development Aid for Afghanistan," Washington Post, January 24, 20I4, at <http://www.washingtonpost.com/world/ national-security/congress-cuts-us-military-and-development-aid-for-afghanistan/20I4/or/24/ 3d4cb8I8-853I-IIe3-bbe5-6a2a3I4Ie3a9_story.html>, accessed on January 25, 2014.

5. Judy Dempsey, "Survey Hints Europeans Are Turning Inward," New York Times, September I6, 2013, at <http://www.nytimes.com/2013/o9/I7/world/europe/survey-hints-europeans-areturning-inward.html $>$, accessed on January 25, 2014.

Asian Survey, Vol. 55, Number 2, pp. 235-248. ISSN ooo4-4687, electronic ISSN I533-838X. (c) 20I5 by the Regents of the University of California. All rights reserved. Please direct all requests for permission to photocopy or reproduce article content through the University of California Press's Rights and Permissions website, http://www.ucpressjournals.com/reprintInfo.asp. DOI: IO.I525/AS.2015.55.2.235. 
also emerged following the decision of the Afghan regime to release 37 men who had been incarcerated in Bagram Prison. These individuals constitute, in the eyes of the U.S. and its allies, "legitimate threats to security" and have apparently been implicated in attacks on NATO forces. ${ }^{6}$

Matters, of course, were compounded in the process of the U.S. forging a status of forces agreement (SOFA) and a bilateral security agreement (BSA) with Afghanistan. In late 20I3, discussions between U.S. National Security Adviser Susan Rice and President Hamid Karzai of Afghanistan reached a deadlock. Among other issues, Karzai insisted that he would sign the agreement only after the U.S. helped him start peace negotiations with the Taliban, agreed to release I7 Afghan citizens being held at Guantánamo Bay Prison in Cuba, and ended the practice of entering Afghan homes when conducting counterinsurgency operations. At stake was not only the presence of U.S. forces but also the very substantial amounts of international assistance that had been pledged to Afghanistan. ${ }^{7}$ Ultimately, Karzai refused to sign any agreement allowing U.S. or NATO troops to stay on Afghan soil beyond the 2014 withdrawal date, ${ }^{8}$ and it fell to his successor to do so literally the day after Karzai left office. ${ }^{9}$

In the absence of the SOFA and BSA, neither U.S. nor NATO forces would have remained in the country after 20I4. Of course, a failure to forge these agreements would have had significant ramifications for other American security concerns in the region. At least one U.S. intelligence estimate in late 2013 concluded that, in the absence of a substantial American military presence beyond 20I4, many of the strategic gains of the past several years could easily be dissipated. The assessment is not without its critics. Some have suggested that it is overly pessimistic and fails to take into account the

6. Emma Graham-Harrison, "U.S. Military Condemns Release of 'Dangerous' Afghan Prisoners," Guardian, January 27, 20I4, at <http://www.theguardian.com/world/20I4/jan/27/us-militarydangerous-afghan-prisoners $>$, accessed on January 28, 2014.

7. Tim Craig and Karen DeYoung, "Karzai Tells Susan Rice of More Demands Extending U.S. Troop Presence," Washington Post, November 25, 2013, at <http://www.washingtonpost.com/world/ national-security-adviser-susan-rice-visits-afghanistan-amid-tension-over-troop-accord/20I3/II/25/ fdof846o-55dd-IIe3-835d-e7173847c7cc_story.html>, accessed on January 25, 2014.

8. Emma Graham-Harrison, "Hamid Karzai Refuses to Sign U.S.-Afghan Security Pact," Guardian, November 24, 20I3, at <http://www.theguardian.com/world/20I3/nov/24/hamid-karzai-refusesto-sign-us-afghan-security-deal>, accessed on February II, 20I5.

9. Ankit Panda, "U.S., Afghanistan Cement Long Delayed Security Agreement," The Diplomat, October I, 20I4, at <http://thediplomat.com/2OI4/Io/us-afghanistan-cement-long-delayed-securityagreement/>, accessed February II, 20I5. 
genuine progress that the Afghan security forces have made in recent years in terms of their training and effectiveness. ${ }^{10}$ Regardless, it is true that the U.S. would not have had a viable set of bases for the drones that it has been using to attack the remnants of al-Qa'ida holdouts along the Afghanistan-Pakistan border. ${ }^{11}$

The U.S. and its allies may well have concluded that 2014 was an opportune moment to reduce dramatically if not terminate their presence in Afghanistan unless the regime met certain minimal expectations. Few policymakers have explicitly invoked the terrible consequences following the precipitous U.S. disengagement from the region in the wake of the Soviet withdrawal in 1989; however, the memories of the brutal and sanguinary civil war that ensued, and the subsequent rise of the Taliban, cannot have entirely dissipated. Still, while the U.S. will not withdraw entirely, it did draw down its force to about I0,000 at the beginning of 20I5, a level it will maintain through the end of the year. ${ }^{12}$ For its part, NATO will have 2,00o troops in Afghanistan under the terms of the SOFA commencing in $2015 .{ }^{13}$ Not surprisingly, for the principal states in the region, not to mention the citizenry of Afghanistan, the state of the country in the wake of the drawdown remains a critical concern. In considerable part, these concerns stem from the ability or the lack thereof of the Afghan security forces and the new government to maintain order and keep the Taliban at bay (or not) as foreign troops draw down.

This collection of articles has brought together a number of well-known scholars and practitioners to discuss the interests, concerns, and likely strategies of a number of key regional actors as the U.S. seeks to make certain critical choices about its future involvement in Afghanistan. The collection also includes essays on the troubled domestic politics of the country, as well

Io. Ernesto Londfio, Karen DeYoung, and Greg Miller, "Afghanistan Gains Will Be Lost Quickly after Drawdown, U.S. Intelligence Estimate Warns,” Washington Post, December 28, 2013, at <http://www.washingtonpost.com/world/national-security/afghanistan-gains-will-be-lostquickly-after-drawdown-us-intelligence-estimate-warns/2013/I2/28/ac6ogf9o-6f32-IIe3-aecc85cbo37b7236_story.html>, accessed on January 25, 2014.

II. David E. Sanger and Eric Schmitt, "Afghanistan Exit Is Seen as Peril to C.I.A. Drone Mission," New York Times, January 26, 20I4, at <http:/www.nytimes.com/20I4/or/27/world/asia/ afghanistan-exit-is-seen-as-peril-to-drone-mission.html?_r=o>, accessed on January 27, 2014.

I2. Michael D. Shear and Mark Mazzetti, "U.S. to Delay Pullout of Troops from Afghanistan to Aid Strikes," ibid., March 24, 20I5, p. AI.

I3. Ibid. 
as perspectives from two of the most critical external actors, the U.S. and U.K. This group of articles shows that the interests and policies of several regional players overlap and diverge in a number of different ways. Even those committed to a stable, prosperous, and peaceful Afghanistan have vastly different views about how such an outcome may best be obtained. The following section summarizes the roles these actors are likely to play in the foreseeable future. All but two of these papers were presented at a conference held on November I-2, 20I3, hosted by the Indiana University (IU) Center for American and Global Security, co-sponsored by the IU Center for the Study of the Middle East, both now in the School of Global and International Studies. The School of Public and Environmental Affairs was a co-sponsor.

\section{SUMMARY OF PAPERS}

Focusing on the American perspective, Larry P. Goodson contemplates future bilateral relations in his article, "The U.S. and Afghanistan after 20I4." As do other authors in the collection, Goodson begins with a brief history of the bilateral relations, noting that the U.S. generally stood at arms'length from Afghanistan. For instance, he observes that Afghanistan was not included in the anti-Soviet Central Treaty Organization (CENTO) that included both Iran and Pakistan (and, until 1958, Iraq). Though there had been some typical I950s-era U.S. development projects in Afghanistan, American attention was not fully focused until the Soviet invasion in I979. Once the Soviets withdrew in defeat, and as a bloody civil war erupted, the U.S. packed up its embassy and went home.

It took the 20oI attacks in New York and Washington for the U.S. to reengage militarily. There is no small amount of irony that once the U.S. managed to install President Hamid Karzai as the leader of the transition by 2002, the remnants of both al-Qa'ida and the Taliban sought refuge in Pakistan. The latter, as noted by Goodson, had, after all, emerged during the Soviet invasion of Afghanistan as the third largest recipient of U.S. foreign aid after Israel and Egypt. Still, once the U.S. shifted its focus to Iraq in 2003, American attention to Afghanistan (and perhaps Pakistan) again suffered. That attention was rekindled when the Obama administration in 2009 ordered a surge of troops to mount counter-insurgency operations, announcing, however, that its troops would be withdrawn by the end of 2014 . 
Goodson thereby argues that the U.S. did not perceive any particular national security interest in Afghanistan prior to the 200I terrorist attacks, with the exception of the era of the Soviet invasion. His article is a cautionary tale that the U.S. may slip into that mode of thinking again, although the delay in the drawdown is a hopeful sign that the U.S. intends to avoid that mistake this time. In the wake of the terrorist attacks, he identifies two American national security interests, namely, destroying al-Qa'ida and ensuring that Afghanistan not be used as a base of operations in the launching of attacks against the U.S. in the future. Goodson identifies four strategies that arose in support of these goals: counter-terrorism, state-building, security-sector reform, and, again in 2009, counter-insurgency. Echoing Shahrani's article, Goodson documents the American reliance on warlords in executing these strategies.

Goodson foresees the emergence of a New Great Game once again being played at Afghanistan's expense. The U.S. appears to have inherited the former British role, and China, that of Imperial Russia. Other contenders will be India, which is, like China, a rising Asian power, one that may well come to contest China's growing influence throughout the region. These two large Asian powers are even now pouring investments into Afghanistan (as other authors document—see below), competing for influence. By far, the largest investors remain the U.S. and its NATO allies, but the populations of these countries are war-weary and unlikely to want to commit many more resources in the future.

Still, even as the Obama administration announced its intention to focus its foreign policy energies on the Pacific and away from the Islamic world (although that has seemingly been more of an aspiration than an achievable policy in the short term), Goodson identifies four U.S. interests in Afghanistan in the post-20I4 dispensation. These are the following: continue to prevent the threat of terrorism on U.S. targets emanating from Afghanistan; prevent the proliferation of nuclear weapons in the region, especially to nonstate actors, given that four of Afghanistan's neighbors are known nuclear powers; maintain regional stability and avoid any spillover of violence among the competing powers that surround Afghanistan; and ensure a sufficient U.S. footprint so that it is not one of the U.S.'s strategic rivals that undergirds stability in the region. Of these four long-term strategic interests, Goodson identifies the second, nuclear proliferation, as the most important, with the latter two being the most difficult to achieve since, in his view, "no vital national security interests now exist in Afghanistan." 
In his article, "The Impact of the 20I4 U.S.-NATO Withdrawal on the Internal Politics of Afghanistan: Karzai-Style Thugocracy or Taliban Theocracy?" Nazif M. Shahrani paints a particularly bleak picture of both the history of the U.S.-led intervention to date and its probable outcome in the future. He notes that there were three objectives for the international coalition after the September II attacks. These were to punish al-Qa'ida and the Taliban for their respective involvement in and tolerance of the attacks on the U.S.; to establish effective governance in Afghanistan and thereby prevent a resurgence of the Taliban; and to enable allied forces to withdraw except for residual forces left to conduct counter-terrorism operations, one presumes in a comparatively secondary role to Afghan forces. In a word, after a war lasting more than 13 years, Shahrani sees only failure for the effort.

Shahrani begins his narrative by briefly recalling the history of Afghanistan from the late nineteenth century through the Soviet invasion in the I970s and its concomitant aftereffects. Over the near century prior to this invasion, Shahrani asserts, the Afghan elites had learned to survive through foreign patronage, but the Soviet invasion destroyed this system. In its place, neighboring states created a new elite system. For instance, the Pakistanis adopted Pashtun jihadis as their clients, though they ensured that these groups would be divided. The legacy of this era survives to the present day in the creation of new elites, at least some of whom owe their allegiance to American patrons, as well as others who have regional allegiances. Disturbingly, Shahrani documents that this system of foreign patronage was intensified in light of the U.S. invasion. It is this new system of elite alliances that was in large part responsible for the ultimate failure of the three goals he identifies as motivating the post-20oI intervention.

Shahrani traces a particularly disturbing proclivity on the part of U.S. officials to emphasize expediency over good governance and the rule of law in Afghanistan. He notes, for instance, that the current Afghan government, being a unity government brokered into existence by the U.S. Secretary of State, was in fact formed in violation of the Afghan Constitution. Along the way, America's man in Kabul, Hamid Karzai, compromised any hope of the emergence of good governance and stable institutions through deals designed to keep him in power over the I3 years since the Bonn Conference in November 200I. Karzai's own patronage resulted in rampant corruption via the appointment of cronies over competent civil servants, including in the Afghan armed and security forces. 
Neil Englehart and Patrick Grant, in their article, "Governors, Governance, and Insurgency in Karzai's Afghanistan: The Limits of Professionalism," make a strikingly counterintuitive argument about the significance and utility of warlords in the Afghan political context. Contrary to the view of most policy analysts and human rights activists, they contend that despite most Afghan warlords' rather sanguinary political record, they can, under the appropriate circumstances, become useful allies in promoting governance. Based upon empirical evidence, the authors demonstrate that those warlords who have the closest ties to a particular province appear to be most successful in containing insurgent violence. In making this argument, the authors contend that incentives shape the behavior of political actors more than character and personality. To that end, they suggest that the national government devise means to draw on the local capacity of particular warlords as a possible strategy to enhance the quality of political order. Such a strategy, they hold, would necessitate the promotion of a more federal structure and the devolution of political authority.

The result has been a continuously perilous security situation, coinciding with the resurgence of the Taliban as a viable alternative to Kabul's deeply entrenched perennial corruption. These events unfolded as the non-Pashtun opposition to Karzai appeared to be in disarray, unable to find a fulcrum around which to balance Karzai \& company's deleterious influence. It is difficult to imagine that the mere delay of one year in the effective withdrawal of U.S. and NATO forces will alter these fundamental facts on the ground. Shahrani concludes that this endemic corruption has given real impetus for the Taliban's resurgence. Given the history of the past I4 years, one might well imagine that to resist the Taliban, the U.S. will continue to support a post-Karzai "thugocracy," dooming Afghanistan to continued instability and institutional failure. Perhaps 35 years of more or less continuous warfare has doomed Afghanistan for the foreseeable future, but one cannot help but conclude that a more felicitous post-200I dispensation might have put Afghanistan on a better path than it now finds itself.

In his article, "China Ponders Post-20I4 Afghanistan: Neither 'All in' Nor Bystander," Andrew Scobell argues that "Beijing's greatest fear is the prospect of turmoil not being contained in Afghanistan and spilling over into neighboring states, including China.” Recalling Stoner's analysis of Russia's attitude, Scobell argues China did not want the U.S. to maintain a permanent military presence in Afghanistan. Still, China fears that Islamic radicalism will 
be resurgent in the wake of the American withdrawal. Accordingly, Scobell foresees that, where China had been fairly hands-off in the early stages of the Afghan war, it has become more engaged in Afghanistan. He anticipates that China may step up its involvement with Kabul in the aftermath of the U.S. withdrawal.

Prior to the terror attacks in the U.S. in 200I, Afghanistan was regarded by China as a peripheral issue, according to Scobell, at least until the Soviet invasion in 1979. At that time, China became concerned that Moscow was attempting to encircle it. With the Soviet withdrawal in 1989, China's fears receded and its foreign policy reverted to its previous state. Yet, as the Taliban rose initially in Kabul, China sought assurances from its leaders that they would not promote unrest among China's Uighur community in the Far West. With the overthrow of the Taliban and Karzai's installation as president, China sought friendly relations with Kabul.

As the U.S. draws down its forces, Scobell argues that China will be motivated by what he terms "two rings of stability." The first ring involves stability within China itself, while the second ring involves stability on its borders. He states that China's leadership is "extremely paranoid and particularly fearful" of perceived threats to internal security that outside threats pose. Scobell documents that some in the Chinese leadership even suspect that U.S. troops on their borders are there at least in part to foment unrest within China.

Accordingly, Scobell identifies four Chinese goals in Afghanistan in the wake of the American drawdown. These goals are "in descending order of importance": containing extremism, limiting the influence of external powers, extracting natural resources, and halting the flow of illegal narcotics. To effectuate these policy goals, Scobell identifies a number of arrows in China's quiver. China can wield its tremendous economic prowess. Scobell notes that China increased its trade with Afghanistan by a factor of more than $\mathrm{I} 2$ over an eight-year period, consisting mostly of goods flowing into Afghanistan.

Yet, it is rather surprising that China has not flexed its considerable diplomatic and military muscles. Still, Scobell argues that with its growing economic interests in Afghanistan, China could well reassess its policies. Indeed, he notes that its relatively aloof stance hitherto could actually increase its influence, since domestic constituencies in Afghanistan might not perceive China as having an untoward agenda. Still, even if China decides to raise its 
military profile in Afghanistan, Scobell does not expect it to play a leadership role in military terms.

Diplomatically, Scobell identifies Pakistan as China's most important card, owing to the tremendous influence China has on the government in Islamabad. Of course, Pakistan itself is motivated by a desire to have a friendly government in Kabul, as it believes such an arrangement gives it "strategic depth." Complicating matters are the well-known close relations between elements in the Pakistani government and security apparatus, and the Taliban. Also complicating matters, as Scobell notes, is that it is not entirely clear that Pakistan has the ability to deliver on any agreements made with respect to Afghanistan. Moreover, despite strong ties between China and Pakistan, some bilateral tensions have arisen. Scobell notes that China is leery about Pakistan's support of terrorist groups outside its borders. It is also concerned about the safety of Chinese workers in Pakistan. Nonetheless, Scobell argues that an agreement between the two countries about a way forward in Afghanistan could significantly expand China's role there. In his view, China might well decide to increase its engagement in Afghanistan, even were the Taliban to rise again in Kabul, because Pakistan, with its close relationship to the Taliban, could well play a mediating role between it and China.

Joseph Y. S. Cheng, in his article, "The Afghanistan Situation and China's New Approach to the SCO," examines China's principal concern of combatting regional terrorism, religious extremism, and separatism through the Shanghai Cooperation Organization (SCO), whose existence China initiated in 20oI. Despite the obvious political and security implications of these three goals, Cheng sees the rise of economic cooperation among the members of the $\mathrm{SCO}$ as an independent goal of the organization, beyond the implications it has on the other three objectives. Tensions within the SCO, however, could be on the horizon. Cheng documents the extent to which China has leveraged its economic power through the SCO, increasing its trade with and holdings in SCO partners. It seems likely that India and Pakistan will join the SCO in the near future, though this would require Pakistan, with its traditionally close relationship with China, to accommodate closer relations between India and China at a time when India may well be expected to begin to play a greater role in Central Asia.

With the election of Prime Minister Narendra Modi in 20I4, Rajendra M. Abhyankar sees a resurgent Indian foreign policy toward Afghanistan in his article, "Afghanistan after the 20I4 U.S. Drawdown: The Transformation 
of India's Policy." In this telling of the tale, since Indian Independence in 1947, Afghanistan has figured in India's tense relations with Pakistan. Still, Abhyankar notes that Indo-Afghan relations were largely "sterile" throughout the twentieth century, from Independence to the Soviet invasion, focusing more on small-scale trade than anything else. It is interesting to observe that, due to the closeness of Indo-Soviet cooperation at the time, India was the only country in South Asia to recognize the pro-Soviet Democratic Republic of Afghanistan. Afterward, with the eventual rise of the Taliban, who were and are the strategic allies of Pakistan's intelligence service, India withdrew its hand in Afghanistan.

In the wake of the 200I U.S. invasion, Abhyankar identifies three distinct periods of India's involvement in Afghanistan. In the initial period, until 2007, India was extremely supportive of the Bonn Conference and the subsequent rise of successive Afghan governments. India took particular pleasure in knowing that President Karzai was partly educated in India. Still, post-2007, India felt increasingly marginalized from Afghan policy: in its view, the U.S. tilted to accommodate Pakistani interests there. In the post2014 dispensation, India is now poised to continue to assert its own interests in Afghanistan, including signing a bilateral agreement in $201 \mathrm{I}$ on continued political, security, and economic cooperation.

Significantly, Abhyankar identifies several Indian interests in Afghanistan. The first is ensuring, to the extent possible, that the wave of radicalism that has seemingly swept Pakistan and Afghanistan does not spread to India. India also seeks to ensure that Afghanistan will not become a safe haven for groups that seek to launch attacks on its territory. Third, India seeks to ensure that Afghanistan develops into a stable and inclusive democracy. On the economic front, India will continue to provide development assistance as it seeks to ensure Afghanistan's integration into the world economy.

India is concerned about what Abhyankar calls the "resilience" of the Afghan state in light of the U.S. and allied drawdown. India, therefore, believes that President Ashraf Ghani will need to focus his attention on building state institutions and capacity, as well as ensuring that parliamentary elections slated for 2015 are conducted in an open and fair manner. Abhyankar identifies several levers available to Indian foreign policymakers to influence a salutary outcome. These include India's "soft power" (derived in part from what he describes as "incredibly positive feelings" the Afghans have for their Indian neighbors); a developing Indo-Afghan strategic partnership; 
continuing development assistance; and India's ties to ethnic minorities in Afghanistan, among other levers.

Vis-à-vis other powers, India will have convergent and divergent interests in Afghanistan. Abhyankar argues that Pakistan, for instance, may well continue to play what he calls a "spoiler" role, attempting to limit India's strategic reach in Kabul. In respect to U.S. policy, while the author notes that India believes American policy has been too indulgent of Pakistan's deleterious role, he foresees that as Indo-American strategic cooperation continues to deepen, there will be greater opportunities for a positive Indian role in Afghanistan. In respect to the other major regional powers, India's strategic vision is closer to Russia's than to China's, as Abhyankar analyzes the issues. This is in large part due to the shared Indo-Russian desire to see a stable and unradicalized Afghanistan, while India looks warily at China's links to Pakistan, especially given Pakistan's support to the Taliban and other Islamist radicals.

Kathryn Stoner's article, "Russia's 2Ist Century Interests in Afghanistan: Resetting the Bear Trap,” identifies Russia's enduring interests in its regional neighbor. Obviously, the Russian Federation does not have the luxury of distance as does the U.S., and economic and security instability in Afghanistan are matters of immediate concern for Moscow. Stoner points out that Russia has its own history in Afghanistan dating at least to the nineteenth century and the Great Game that the Russians "played," vying with Great Britain for control over Central Asia. Further, tempered by its own defeat in the Soviet era, Russia has balanced an imperative not to be re-drawn into Afghanistan's precarious security situation against the possibility of rising American influence on Moscow's doorstep.

Stoner, too, begins her narrative with a historical perspective. She notes, for example, that the Stalinist era linked Moscow's interests more firmly with Afghanistan than in the Imperial era, through the creation of the predominantly Islamic Soviet republics of Central Asia. Because borders were haphazardly drawn, tribal and ethnic affiliations crossed what have since become international boundaries. In the meantime, the prospect of a communist government collapsing on the borders of the Soviet Union in 1979 created a strategic imperative for intervention. The disastrous results of that effort have not been forgotten by the current leadership in Moscow.

Those memories, according to Stoner, have led to a relatively low level of engagement by Russia with Afghanistan. On the other hand, she notes that 
Vladimir Putin, whom she identifies as a post-Soviet "realist," is motivated in no small part by a desire to counteract U.S. policy as well as a rising China. To that end, Stoner documents Putin's disturbing belief that Western policies of containing Russia, which he places as far back as the eighteenth century, are still in play today. Motivated as Putin is by this reading of history, Stoner foresees that a Russian priority will continue to be to limit U.S. influence in Afghanistan post-20I4.

Yet, Stoner argues that Russia's interests in Afghanistan will not be merely to negate presumed American ascendancy there. Rather, it will have its own positive agenda, motivated in no small part by a geostrategic interest in peace and stability in Central Asia. To that end, she argues that Russia will seek to promote economic and political stability in Afghanistan, in the hope that this will engender greater stability throughout the region. In no small part, the ethnic and religious internecine fighting so close to its borders is not something about which Russia can be sanguine. To further these goals, Russia has pledged to increase its economic involvement in Afghanistan, including continuing certain Soviet-era projects. Of course, in common with regional states as well as the international community at large, Russia will continue to have an interest in constricting if not eliminating the Afghan heroin trade.

Stoner notes that scholarly opinion is divided over how central Afghanistan will be to a newly revitalized Russian foreign policy, beyond the "narrowly defined interests" outlined above. She notes, for example, that while Moscow supported the establishment of the International Assistance Security Force (ISAF) in Afghanistan after the September II attacks, Russia did not actually participate in it. In the immediate aftermath of those attacks, Russia did indeed support the U.S. anti-terror effort in Central Asia, but that support has waned over the years. Stoner argues that Putin came to distrust U.S. intentions there and began to obstruct American efforts, though he may now fear a security vacuum in the post-20I4 period. Even though the potential spill-over of problems in Afghanistan into Chechnya, and elsewhere in Central Asia, motivates some of Putin's fears, any impulse for meaningful cooperation with the U.S. is tempered by tensions, especially in Ukraine.

The last article in this collection is "Assessing Britain's Role in Afghanistan," by Shashank Joshi. What is immediately striking about this article, in contradistinction to the others in this special issue, is that undergirding Britain's future involvement in this theater are the cold, harsh realities that 
confront London. Britain's role will be limited in no small part because it cannot afford to do more. Sic transit gloria mundi!

This is not to say, however, that Britain's role in Afghanistan will be nugatory after the drawdown. Joshi persuasively argues that the U.K. still has a set of interests - and a range of abilities, some of them unique, with which to effectuate those interests. These include counter-terrorism, counternarcotics, a broader interest in combating transnational threats while promoting human rights and state-building, and showing that Britain is committed to the transatlantic alliance with the U.S. Too, Joshi argues that Britain's withdrawal from Iraq in 2009 was largely perceived in the U.K. as a strategic defeat. Britain's own sense of its prestige in world affairs, therefore, will not allow it to withdraw completely from Afghanistan, lest a similar impression arise again.

Still, according to Joshi, there is no unanimity even in respect to some of the national interests that successive British governments have identified. The director-general of Britain's domestic intelligence agency, $\mathrm{MI}_{5}$, in $20 \mathrm{I}_{3}$ failed to mention Afghanistan in a list of leading security threats. Joshi quotes other security analysts and diplomats as suggesting that Britain's internal security profile could actually be improved through reduced engagement in Afghanistan, thereby leaving it to "the countries of the region" to deal with radical militancy. While such sentiments do form a part of the overall debate in the U.K., Joshi nevertheless notes that these views have not been adopted by the country's leadership.

Joshi pauses to emphasize that, in the post-20I4 dispensation, Britain will have withdrawn not all of its troops from Afghanistan but only its combat troops. It will continue in its mission of training, and forces responsible for such training and mentoring of Afghan troops may well remain for the foreseeable future. Significantly, it will fall to British forces to train Afghan officers, in what the press calls Afghanistan's "Sandhurst in the sand." Moreover, British special forces are likely to continue to be active in-theater, as will its intelligence services. These services have demonstrated unique abilities since the I980s. Such operations are termed by Joshi "coercive instruments."

Joshi identifies two other forms of engagement that the U.K. will undertake in the post-20I4 period. The first involves funding. Britain's share of external funding for Afghanistan will, however, be modest. For instance, Joshi points to a commitment of providing $£$ I78 million (roughly US\$270 million) for civilian training and expenditures, a sum dwarfed by the U.S. commitment of $\$ 7.7$ billion. Similarly, the U.K. committed a sum of $£ 70$ 